\title{
Reduction and the Question of Beginnings in Husserl, Fink and Patočka
}

\section{Witold Płotka ${ }^{1}$ (D)}

Published online: 18 October 2018

(c) The Author(s) 2018

\begin{abstract}
The article is an attempt to define reduction as the beginning of philosophy. The author considers such questions as: What motivates a phenomenologist to do reduction? Can one speak of philosophy before reduction? What is the essence of reduction? To answer these questions the author refers to Husserl, Fink and, Patočka, and tries to show that reduction is to be understood as an unmotivated expression of philosopher's will to overcome evidence inherent to natural attitude. The author argues that reduction enables one a problematization of the world as such. Finally, reduction is defined as an attempt to take doing philosophy seriously.
\end{abstract}

Keywords Naivety · Natural attitude - Questioning · Subjectivity · Immanence · Existence $\cdot$ Epoché $\cdot$ Husserl $\cdot$ Fink $\cdot$ Patočka

\section{Introduction}

To say that phenomenology is primarily a method seems to be a truism (Bernet et al. 1999: 58-87; Zahavi 2003: 43-68). Some believe that the purpose of this method is to highlight a new area of being, i.e., a transcendental domain understood as a space of pure consciousness, which is supposed to be the equivalent of establishing a new beginning of philosophy. Certain misleading statements made by Husserl have undoubtedly contributed to such interpretations. It seems that the theory of reduction is of key importance in this context because-it might be arguedeverything that does not belong to the transcendental domain must be reduced, i.e., ignored and rejected. But why should these elements be rejected? Is this interpretation of the theory of reduction justified at all? In the present article I want to depart from such popular interpretations and describe reduction as a way of understanding the world and consciousness from a philosophical standpoint. I want to demonstrate

Witold Płotka

witoldplotka@gmail.com; w.plotka@uksw.edu.pl

1 Institute of Philosophy, Cardinal Stefan Wyszynski University in Warsaw, Wóycickiego 1/3,

Building No. 23, 01-938 Warsaw, Poland 
that, rather than instituting a new area of being, the aim of reduction is to change the attitude to being and try to reflect upon it philosophically.

It is true that there is no consensus among phenomenologists concerning either the exact sequence and procedure of reduction or the assessment of its efficiency and even possibility. ${ }^{1}$ In fact, the problem of reduction may be pared down to an attempt at identifying its process, individual steps and purposes. This approach, however, seems to miss the very aspect that makes reduction possible-in other words, its beginning. This is why, in this article, I suggest to treat reduction-following Lenkowski (1978: 299)—as the beginning of philosophical reflection, i.e., as a condition of possibility for phenomenology itself. Hence, one of the fundamental questions relates to the motives behind reduction. In Erste Philosophie Husserl underlines that the beginning of philosophy requires "specific motivation" (besondere Motivation) (Husserl 1959: 98) as the philosopher should start by freeing himself of his interest in the world and suspending his judgement of it. "What-Husserl asks_- can be the motive here?" (Husserl 1959: 98). In this context, Mohanty claims that the question about the motivation for reduction can be answered in three ways: (1) "reduction is totally unmotivated, in exercising reduction the philosopher is exercising his freedom not to participate in the beliefs of the natural standpoint"; (2) "reduction is motivated by one of many possible mundane motives - for example, the idea of philosophy as first science or the idea of providing foundation for all cognition, these ideas being available from the history of human thought"; finally, (3) reduction is ambiguous since "in the natural attitude, reduction appears completely unmotivated, in a philosophical attitude which seeks to understand the natural attitude, it finds sustenance in the historically available ideas of first science and foundational cognition, but the true sense of reduction emerges only at the end and not at the beginning" (Mohanty 1997: 57).

Considering the problem of the beginnings of philosophy and the question of the motivations for reduction in this article, I will draw upon the reflections of three thinkers-Husserl, Fink and Patočka - in an attempt to advance more arguments in favour of the first answer suggested by Mohanty. Even though the three thinkers were in contact with one another and their theoretical propositions were the fruit of their discussions, ${ }^{2}$ I will not delve into the question of potential influences and historical circumstances. Instead, I want to demonstrate how they understood the essence of reduction as the beginning of philosophizing. At the same time, my aim is to show that reduction takes the form of an inquiry into what is obvious (Płotka 2012). The obvious does not provoke questions, which is to say that it provides no motivation to initiate philosophical reflection. It is only from this perspective that

\footnotetext{
1 For example, Merleau-Ponty believes that total reduction is not possible as the philosopher cannot exclude himself from the world's acceptance. As he famously states it, "[t]he most important lesson which the reduction teaches us is the impossibility of a complete reduction. This is why Husserl is constantly re-examining the possibility of the reduction. If we were absolute mind, the reduction would present no problem. But since, on the contrary, we are in the world, since indeed our reflections are carried out in the temporal flux on the which we are trying to seize (since they sich einströmen, as Husserl says), there is no thought which embraces all our thought" (Merlau-Ponty 2002: xv).

${ }^{2}$ E.g., Heitz and Nessler (1999), Bruzina (1998, 2004).
} 
the obvious, accounted for as the obvious, can be problematised. Thus, approaching the obvious as a problem seems to be the unmotivated beginning of philosophizing. In the present article, I will take a closer look at the reasons for which reduction should be treated as unmotivated.

In order to present reduction as a special form of inquiry into the obvious and an unmotivated beginning of philosophical reflection, I will first refer to Husserl's philosophy. Doing so, I want to show the limitations stemming from the common understanding of reduction as reducing the transcendental to the immanence of consciousness. It seems that this exposition offers no explanation of the beginnings of reduction, situating the motivations for reduction vaguely inside the world. There appears to be more potential in the conception of attitude change that places motivations for reduction in the domain of volition. I will then move on to reconstructing selected elements of Fink's "phenomenology of phenomenology". I will point to instances when Fink radicalizes the understanding of reduction and accounts for it as an unnatural attitude that consists in overcoming the naivety of the world. Like Fink, I will eventually approach reduction as a way to dehumanize philosophy and an expression of the will of freedom. Finally - following Patočka-I will take on the question about the beginning of philosophizing in the context of Patočka's concepts of care for the soul and the three movements of human existence. The Czech philosopher seems to radicalize the understanding of reduction: not only does he depart from understanding it as isolating the immanence of consciousness, but he also accounts for reduction as an expression of the objection against the obviousness of the world. As I will demonstrate in the last part of the article, Patočka sees reduction as a continuous inquiry which constitutes the subject of philosophy as the subject of freedom.

\section{Reduction, Subjectivity, and the Theory of Two Attitudes in Husserl}

For Husserl (1994: 285-286) reduction is the very "heart" of a phenomenological philosophy. Even though he treats reduction as centrally important for his philosophical project, his definition of the concept is "not always crystal clear" as has been observed by Zahavi (2003: 76). This leads to potential misunderstandings and distortions. Such problems begin with the very lexical understanding of reduction which, in the most general sense, seems to be about bringing one element back to another. In the case of phenomenology, reduction would be a reduction to subjectivity, i.e., an account of the transcendental field where the meanings of the world are constituted by consciousness. In this part of the article, I want to identify the limitations of this understanding of reduction and account for reduction as a way of changing the attitude from the natural to the philosophical, which, eventually, entails accounting for obviousness as obviousness.

The very idea of reduction is present in Husserl already in his early publications and lectures (Lohmar 2012). One of the fullest accounts of reduction is to be found in The Idea of Phenomenology where it is applied to problematize cognition as such, whereas the fundamental question concerns the objective validity of cognition. In this context, Husserl differentiates between two pairs of concepts related to 
transcendence and immanence. On the one hand, one speaks of transcending the object of cognition when "the known object is not really [reell] contained in the act of knowing" (Husserl 1999: 27), whereas one refers to an object as immanent when it is effectively contained in the act of knowing. On the other hand, what is transcendent is not obviously given, i.e., it is something vague and unclear, whilst immanence is "absolute and clear givenness, self-givenness in the absolute sense" (Husserl 1999: 27). How are the two pairs of concepts different?

The former relates to the Cartesian opposition of the object of cognition and the act of knowing. In this case, the only thing we may be certain of is the subjective aspect of cognitive experience and the cognitive act, but never the object itself. The latter opposition stems from the phenomenological distinction between the obvious and non-obvious givenness of the object. As long as the object is transcendent in the latter sense, it can be brought to obvious givenness, i.e., immanence. The shift from one element to the other is made possible by the method of reduction. ${ }^{3}$ Put simply, reduction to consciousness - according to the presented reading of Husserlseems to be reduction to obviousness. Therefore, reduction can be interpreted as a methodic process of changing what is not obvious into what appears to be obvious. However, to be precise, obviousness cannot be identified with immanence since this reading could suggest that Husserl is a kind of a Cartesian thinker. Rather, obviousness is the way of givenness of the object, and as such it can present different stages from a vague till clear presentation. In any case, the phenomenologist takes the stance of an "uninterested observer" (Husserl 1959: 91; 1968: 341), his only task is to capture what manifests itself as obvious. Again, here the obvious is the aim of reduction and not a presupposition of the methodological procedure.

This approach is motivated not only by disappointment in sciences that are not able to provide philosophers with infallible foundations of knowledge, but also by the idea of philosophy as "rigorous science" and "philosophia prima". In other words, it is motivated by the history of human thought (Husserl 1959: 3; 1960: 1). This should come as no surprise because "[i]f reduction is to open for us access to the transcendental domain, the reduction has to be motivated from within the mundane order" (Mohanty 1997: 57). While motivation is the product of history, reduction itself is not so much a repetition of the Cartesian way as its radicalization. Hence, the philosopher must eventually "reject nearly all the well-known doctrinal content of the Cartesian philosophy" (Husserl 1960: 1). Paradoxically, the Cartesianism of phenomenology leads to the rejection of Cartesianism (Landgrebe 1963; Luft 2004: 205-208). Consequently, even if reduction is motivated by an element occurring before reduction (history of human thought), the content of the element is finally rejected anyway. In this approach, it is evident that one of the fundamental properties of reduction is its radicalism that consists in taking the demand to ground knowledge to the extreme.

\footnotetext{
3 “The 'phenomenological' $\dot{\pi} \pi \circ \chi \eta$ will deserve its name only by means of this insight; the fully conscious effecting of that $\dot{\varepsilon} \pi \mathrm{o} \chi \dot{\eta}$ will prove itself to be the operation necessary to make 'pure' consciousness, and subsequently the whole phenomenological region, accessible to us" (Husserl 1982: 66).
} 
However, the method of reduction presented above - as motivated by and radicalizing the history of thought—has one fundamental flaw: it stems from specific motives but does not clearly define the purpose it wants to attain. Husserl says: "so one is at a loss, at first, to know what has been gained by it, much less how, starting with this, a completely new sort of fundamental science, decisive for philosophy, has been attained" (Husserl 1970: 155). Hence, we might expect that, in order to start philosophizing, a different beginning (ein anderer Anfang) is required, a beginning that would reflect upon the objectives of cognition and science (Husserl 1959: 254). If the objectives were really to be defined as "absolute and clear presentation", it would in fact be a dogma that would not correspond to the radicalism of reduction. ${ }^{4}$ This is why Husserl warns that "it is all too easy right at the very beginning to fall back into the naive-natural attitude-something that is very tempting in any case" (Husserl 1970: 155). After all, reduction is supposed to be a constant drive towards obviousness, rather than its dogmatic affirmation. Or perhaps, to put it in yet another way, reduction is a problematization of obviousness. In addition, it is not clear when philosophizing begins: Does philosophy begin by taking up Descartes' intuition or by opposing it? If one is inclined to the former, philosophy is a simple repetition of history, whereas in the latter case the motives behind the radicalization and eventual rejection of Descartes remain unknown. This is why it is difficult, if not impossible, to identify the beginning of philosophy. These shortcomings seem to be addressed by the doctrine of the change of attitude from the natural to the philosophical.

The natural attitude does not care about justifying cognition. Of course, while being in the natural attitude one can attempt to justify his or her opinion, but to justify an opinion in the natural attitude still does not mean that justification was made outside the natural attitude. What is at stake here is that justification in the natural attitude does not equal justification in the philosophical attitude. In the former, the object of cognition is recognised as accepted or "simply existing" (Husserl 1982: 51f.; 1999: 15-17; 2002b: 280f.). In short, the meaning of the world is already presupposed. Conversely, in the philosophical attitude, we do ask about cognition, its justification and structure, which means that it is only in this attitude that cognition is presented as a problem. Here, we ask about the meaning of the being of the objects, and this reduction is a change of attitude which consists in "suspending" the thesis of the natural attitude, i.e., making the thesis of its existence problematic (Husserl 1982: 57f.). Although this general thesis lays the foundations for the natural attitude, it is not really expressed there (Boehm 1981: 67; Staiti 2009: 226). The thesis is formulated only in the philosophical attitude which, ultimately, is an attempt to seriously think of the non-existence of the world (Husserl 1959: 69). ${ }^{5}$ If it is so, then the natural attitude emerges only in the philosophical attitude or, in other

\footnotetext{
${ }^{4}$ Tugendhat (1970: 194-196) binds this aspect of phenomenology with a dogmatic motif of Husserl's philosophy which consists in an uncritical affirmation of evidence as the ultimate aim of phenomenological analyses.

5 This is mentioned in the experiment of an "annihilation of the world" from Ideas I in which Husserl (1982: 109f.) suggests to take the possibility of world's non-existence seriously.
} 
words, it is discovered only when problematized. Eventually, the conception of an attitude shift leads to three important consequences.

First, it broadens the concept of obviousness, taking it beyond the narrow framework of obviousness understood as "absolute and clear presentation". Obviousness is a way of presenting what is experienced. In the words of Husserl, "[e]vidence is, in an extremely broad sense, as 'experiencing' of something that is, and is thus [von Seiendem und So-Seiendem]; it is precisely a mental seeing of something itself [Esselbst-geistig-zu-Gesicht-bekommen]" (Husserl 1960: 12). Thus, from the perspective of the philosophical attitude, the obviousness of what exists is accounted for as problematic. This means that obviousness is a problem only for the philosophical attitude. There is no point to reflect on this kind of obviousness if it is not accounted for as obviousness. In this context, obviousness is a method of presenting what is given in the natural attitude. The aim is to reflect on obviousness as such, with all its degrees and forms, rather than to observe it (Husserl 1984: 154f.; 1996: 326f.; 2001: 60 , footnote). In the end, obviousness is not only the quality of what is given directly but also applies to cases where givenness is vague and unclear (Husserl 1996: 328).

Second, the two attitudes are linked by naivety that characterizes the natural attitude and is overcome in the philosophical one. For Husserl (1959: 18; 1996: 319f.) the fundamental task of philosophy is to go beyond naivety. Here, naivety can be understood broadly as an impossibility to justify the general thesis of the natural attitude when such an attitude is adopted by a philosopher. However, naivety does not exist in the natural attitude as such. Instead, it is experienced by the subject while not being a separate object; it is presented by the modus "I-know-nothingof-it" (Davon-nichts-Wissen) (Husserl 2002b: 225). It is accounted for only from the perspective of the philosophical attitude. This in turn means that by accounting for naivety and going beyond it, the philosopher departs from the natural attitude. Therefore, to quote Luft (2004: 160), "seeing the natural attitude as naive already means having left it, but in a way that is not naïve". But how to account for naivety in a way that is not naïve itself? Calling naivety to question or accounting for it as naivety is a continuous process (Husserl 1959: 332) reflected by a continuous renewal of reduction (Płotka 2012).

Finally, the theory of attitude change enables us to reconsider the issue of the motivation for reduction. The philosophical attitude is presented as a radical departure from the natural one. ${ }^{6}$ This is enough of a reason not to look for the motivation behind reduction in the natural attitude. Hence, in the philosophical attitude, reduction is totally unmotivated, although necessary. What is crucial here is that the change does not begin in the natural attitude: rather, the natural attitude itself emerges when reduction has already taken place. Of course, before reduction the natural attitude is already at play; what changes after reduction is the need to understand adequately the meaning of the natural attitude which, in turn, was not

\footnotetext{
6 "Die Epoché als Seinsinhibierung des gesamten natürlichen Lebens ist nicht eine Spaltung innerhalb dieses natürlichen Lebens selbst, sondern als radikaler Bruch mit diesem natürlichen Leben gleichzeitig eine Ab-Spaltung von ihm. Der hierdurch etablierte Zuschauer im eigentlichen Sinn hat nun das gesamte natürliche Leben, freilich ins Transzendentale gewendet, zum Thema" (Luft 2003: 40).
} 
explicitly described. Thus, the essence of reduction is that it remains unmotivated and, as such, it is an expression of the philosopher's freedom. Broadly speaking, freedom is here understood as a possibility of being distanced from the natural attitude. Given this, Husserl (1994: 287) is strict in claiming that reduction is made possible by freedom. Establishing the philosophical attitude is therefore a matter of will rather than cognition. Husserl points out that "reflection as such originates in willing" (Husserl 1959: 6f.), underlying that self-reflection (Selbstbesinnung) is a matter of a free and unmotivated decision to choose a different (from the natural) form of life (Husserl 1959: 155; 2002b: 100f.). As Husserl says on another occasion "philosophy—wisdom (sagesse) — is the philosophizer's quite personal affair" (Husserl 1960: 2).

In conclusion of this part of the article, it is worth noting that the conception of reduction, a cornerstone of transcendental phenomenology, has caused a rift among Husserl's disciples (Bostar 1994). Of course, Husserl did work on the idea of reduction throughout his career from The Idea of Phenomenology, through Ideas $I$, till the Crisis, not to mention hundreds of his research manuscripts, and in result he formulated a complex theory of the "ways to reduction" (Kern 1962) which, in turn, can be understood as the description of the beginning of reduction. ${ }^{7}$ In this vein, however, Husserl metaphorically speaks of reduction rather as a "gate," than as a "way," or "road," " what gives an impression that reduction has to be expressed rather as an unmotivated beginning (the "gate"), than as an organized process (the "way," or "road"). If this reading is adequate, reduction marks a line between the natural and philosophical attitude. Thus we need to stress that the idea of reduction makes it possible to explain the beginnings of philosophy as an attempt to account for and leave the existing naivety of the natural attitude. From this standpoint, reduction is the beginning of philosophy as, besides creating the philosophical attitude, it also establishes subjectivity as a subject of philosophy. All things considered, it is only the unmotivated and free reduction that discovers transcendental subjectivity. The discovery has the nature of willing and a drive to establish philosophy. This is the ultimate sense of an attitude: it is a direction of will (Willensrichtung) (Husserl 2002b: 42, 105). Reduction is therefore expressed by the statement: "I want to go beyond the obviousness of the natural world" and, as such, it is a change of attitude (Einstellungsänderung) (Husserl 2002b: 225). Through reduction, I want to account for the world as a problem that is no longer self-evident or obvious (Husserl 2002b: 481f.). ${ }^{9}$ It is worth adding in this context that the phenomenologist is the philosopher of beginnings not because he goes back to consciousness that provides the world's foundation, but because he keeps starting anew: wanting to be a philosopher,

\footnotetext{
7 I am thankful to the anonymous reviewer of the Human Studies for this interesting suggestion.

8 To be precise, Husserl writes that there is no "royal road" which leads to the "kingdom of philosophy". He notes: "Es gibt keinen Königsweg in die Phänomenologie und damit in die Philosophie. Die phänomenologische Reduktion ist die eine und einzige Eingangspforte, die in das philosophische Reich hineinführt" (Husserl 2002a: 74).

9 As Husserl (2002b: 481) writes, what is self-evident from the perspective of the natural attitude becomes incomprehensible (Unverständlichkeit) in the philosophical attitude.
} 
I perform reduction that creates and maintains the division into two attitudes. These issues are brought up by both Fink and Patočka.

\section{Situatedness of Reduction According to Fink}

In his early philosophy, Fink was clearly influenced by Husserl treated both a subject of criticism as well as a departure point for continuation and radicalization. He understood his theoretical position as a "phenomenology of phenomenology" (Phänomenologie der Phänomenologie) (Luft 2002; Moran 2007) with the possibility of reduction as one of the main areas of focus. According to Fink, being a science of the beginnings of philosophy that strives to legitimize itself, phenomenology should start with the question about the conditions for its own possibility, i.e., explain the possibility of reduction as such. However, as has been demonstrated by Husserl, the nature of reduction is ambiguous: in the natural world, there are no motives for performing it, whereas in the philosophical attitude, it appears to be indispensable. In this part of the article, I will look at Fink's attempt to clarify this in more detail.

Fink believed that what Husserl presented in his Ideas I was not so much a developed theory of reduction as its first outline. At the same time, he underlined that this exposition was not wrong but preliminary and thus limited. ${ }^{10}$ The point is that Husserl advocates for excluding the transcendent, that is the world, but does not fully explain what we should understand by a "worldly" being. As a result, the exposition is deficient in that it does not legitimize reduction fully. In addition, as Fink (2008: 54) underlines, Husserl's proposal in Ideas $I$ is in fact to restrict phenomenology to a form of noematics as the only achievement of reduction is that it highlights the subjective-objective correlation. Thus, what reduction achieves in this exposition is the immanence of experiencing time (Fink 2008: 351). Consequently, this understanding of reduction may at most present is the first form, but it definitely does not express its essence. The purpose of reduction is rather to overcome the appearance of consciousness as given in the form of time immanence. ${ }^{11}$ In other words, reduction determines a specific research attitude that manifests itself by calling into question and overcoming preliminary results in order to eventually problematize naivety as such.

\footnotetext{
10 "The presentation of phenomenological reduction that we find in Ideas can no longer be maintained. (Not because it is utterly false, but because it is wrongly understood as reduction to the domain of immanence)" (Fink 2008: 462).

${ }^{11}$ As Fink claims in the text attached to Husserl's Crisis-book, "[j]ust this typical familiarity and pregivenness of 'consciousness' in its rough articulation (which suffices for everyday life) as acts, actions, experiences [Akte, Handlungen, Erlebnisse], etc.- - just this familiarity gives rise to the illusion that consciousness is something immediately given. The intentional analytics of phenomenology, however, destroys the illusion of the 'immediate givenness of consciousness' and leads one into a science of a new sort that is difficult to sustain, where one gradually learns to see and to grasp for the first time what consciousness is" (Husserl 1970: 386-387).
} 
Already in his earliest works, Fink underlined that one cannot really pose questions about naivety. ${ }^{12}$ Still, if reduction cannot be reduced, how can it be possible at all? In order to answer this question, we must take a closer look at naivety itself and show how it is given in the natural attitude. Fink (1966: 12) describes this state as forgetting about the general thesis of the natural attitude. The world is anonymous and becomes clarified as a problem only by reduction: "[a] worldly anonymity of transcendental life is illuminated by phenomenological reduction" (Fink 2008: 46). In this context, reduction is a fundamentally unnatural gesture of the philosopher who wants to break with naivety. It is used to ask about what cannot really be the object of questions in the natural attitude (Fink 1995: 33-34). Seen from this perspective, reduction is based on assumptions described by Husserl as the "natural attitude" (Fink 2006: 93). Now, without naivety it is difficult to think about reduction as the natural attitude is the very state where reduction consists in forgetting about the world, as a result of which the world is eventually treated as a dogma that does not raise any doubts or questions (Fink 2008: 89). It is only in reduction that the world is accounted for as an object of a philosophical reflection (Fink 2008: 168). One should not be surprised therefore that Fink writes about an aporetic (Fink 2008: 12) and paradoxical (Fink 2008: 429) nature of reduction. All in all, the aim of reduction is to abolish naivety, but the philosopher has no incentive to perform it as long as he maintains a naive attitude towards the world. It is for this reason that Husserl insisted firmly that "[a] universal epoché is not only not feasible in the natural attitude, but is senseless" (Fink 1995: 36).

Reduction is to enable philosophers to depart from the natural attitude. This means that they must stop being what they were before, i.e., a subject of a naively accepted world. Fink (1995: 39-40) describes this transition as a un-humanization (Entmenschung) of man who is expected to go beyond natural obviousness. Indeed, human beings are naturally submerged in the world and experience it thoughtlessly. Reduction breaks away from this attitude and, in this sense, it is basically an annihilation of humanity that characterized the human mode of being in the world. Fink (2006: 280; 2008: 63, 117-118, 167) would go back to this expression on many occasions, trying to clarify it as self-abolition (Selbsthebung) of man (Fink 2008: 463). In reduction, a philosopher realizes that the world's naivety is accepted as a forgotten foundation of the natural life. In this way, reduction does change the philosopher's attitude by departing from the natural attitude. This, however, makes, as Fink $(2008: 94,194)$ would have it, a tragedy of our life.

The paradoxical and aporetic nature of reduction means that its purpose is to break with the natural attitude, but the very concept is transcendental. Thus, the dogmatism of the world, i.e., its naivety, emerges after reduction. As it was underlined by Fink, "[i]t is not a dogmatism before the reduction, but a dogmatism after the reduction" (Fink 1995: 111). What is the main achievement of reduction, thus understood? It constitutes the subject of philosophy as a transcendental, uninvolved

\footnotetext{
12 In the article in which Fink juxtaposed Husserl's phenomenology with neo-Kantian objections, he underlines that "[t]he question about the source of the world cannot be asked in naivety that still constitutes the world as the totality of things in themselves" (Fink 1966: 102).
} 
observer who provides the condition for the possibility of involvement in the natural attitude (Fink 1995: 42). This is because the transcendental subject constitutes the sense of the world, i.e., it enworlds itself in a continuous and uninterrupted process of constitution. Even tough, in this context, reduction is unmotivated by the natural attitude, it does take place in a specific situation. One might say that reduction is situated in a specific way. Fink $(2006: 81,168)$ describes this situation as facticity submerged in the intersubjective world; here, reduction is temporal, not as a sequence (which would suggest its natural motivation) but as a "blink of an eye" (Augenblick). It is a moment when the subject understands itself and the world. This is why " $[t] h e$ 'natural attitude' is a situation of reduction" (Fink 2006: 274). Reduction results in a division into a transcendental subject and the stream of naturally experienced life. It is only thanks to this separation that it is possible to turn the world into an object of philosophy, i.e., philosophy itself, mutatis mutandis.

For Fink, just like for Husserl, reduction is not motivated by the natural attitude, even if it is situated in it. In this attitude, the question expressed by reduction cannot be formulated at all. The very possibility of reduction, therefore, does not come from the world but from the philosopher. In other words, reduction is the expression of freedom, ${ }^{13}$ and thus an attitude. Fink claims that "phenomenological reduction is not a method that can be learnt once and for all, but it is a task of philosophy to the extent that its telos represents human freedom" (Fink 2006: 222). Hence, reduction is unmotivated in that it is the expression of the philosopher's freedom. Husserl's assistant stresses that reduction is the articulation of the "will of freedom" (Wille zur Freiheit) (Fink 2006: 222), which means that it is a form of freeing a philosopher of the world (Fink 2008: 168). Here, reduction does not have a cause, but it does have a purpose: a radical questioning of the world's acceptance and freeing the world up as the object of philosophy. It is for this reason that Fink treats reduction as the beginning of philosophy as such. This is its positive aspect. Thus, as it was stressed by Luft, reduction should not be understood as annihilating the world: "[i]t should also be understood in a positive sense as the opening of the domain of transcendental subjectivity. Thus, the thesis about freedom answers the question about the How of epoché and reduction by referring to human freedom which makes it possible to put aside the general thesis" (Luft 2002: 81). As such, reduction is a breakthrough or breaking away but in the sense that it sets a philosopher free. And it is with this meaning in mind that one can talk about philosophy as the beginning: it constitutes itself (Fink 1966: 194).

Fink's philosophy stems from an attempt to radicalize Husserl's phenomenology and in particular from the question about the conditions for the possibility of reduction. Just like his teacher, Fink accounts for reduction as an unmotivated (in the natural sense) expression of the philosopher's will to establish philosophy as such. In his descriptions, however, reduction is further characterized as a "blink of

\footnotetext{
13 According to Bruzina (2004: 131), the methodological core of phenomenology is encapsulated in enquiry and freedom as phenomenology is supposed to lead beyond presupposition that are characteristic of the natural attitude, and thus discover the source of human life and the hidden meaning of what is presupposed.
} 
an eye" (Augenblick) in which philosophy formulates a question that could not occur at all in the natural attitude. This moment may be understood as accounting for the world as problematic. ${ }^{14}$ For Fink, reduction is an attempt to overcome successive degrees of naivety which consists in forgetting that naivety itself is created by reduction. However, if reduction creates naivety, then, by its very nature, it can never be fully ended. Ultimately, "reduction is never finished once and for all" (Fink 2006: 245). ${ }^{15}$ Instead, it consists in a continuous renewal or rather a continuous act of freeing oneself from the naivety of the world. Eventually, reduction, thus understood, establishes philosophy and is its beginning.

\section{Patočka on Reduction and Freedom}

Patočka's philosophy is a confluence of themes present in Husserl, Heidegger and Fink. ${ }^{16}$ The Czech philosopher also interprets reduction in terms of freedom, underlying that epoché constitutes a new form of experiencing the world as an area of appearance. Even though he takes over certain themes, he is far from doing so without critical reflection. For example, Patočka rejects the understanding of reduction as a methodic way to isolate the area of immanence of the transcendental self, insisting upon the concept of the embodied subject and calling his approach an asubjective phenomenology (Patočka 1970; 1988: 217-248). But this is not where the novelty of Patočka's approach to the subject lies. What seems to be the most important for the interpretation of reduction as the beginning of philosophy is rather his concepts of the care for the soul and the three movements of existence. This part of the article will focus on how Patočka accounted for these issues in the context of freedom.

As has been mentioned, Husserl understood reduction as methodic isolation of the area of pure consciousness as immanence. To understand immanence only as being effectively contained in consciousness and not as an absolute certainty would in fact restrict the field of potential phenomenological studies to the study of immanence. This criticism is picked up by Patočka (1992: 137) who claimed that, thus understood, reduction is a form of immanentizing the object of studies as, instead of asking about the "thing in itself," one investigates the transcendental origin of the object in immanence. Hence, a phenomenologist is finally interested not so much in phenomena as phenomena as in the domain of absolute being, i.e., the immanence of transcendental subjectivity (Patočka 1988: 225). In other words, Patočka (1992:

\footnotetext{
${ }^{14}$ Fink understands reduction as radical inquiry or questioning and he states in the Sixth Cartesian Meditation that " $[\mathrm{t}]$ he motivation for the action of reduction is the awakening of a questionableness that indeed enters the scene in the natural attitude, but which in principle 'transcends' the horizon of all questions that are possible within the natural attitude" (Fink 1995: 37).

15 For Fink, "the phenomenological reduction is something which must be continually repeated in phenomenological work" (Cairns 1976: 43).

16 Of course, Patočka's thinking was shaped by discussion not only with Husserl, Heidegger and Fink, but also with Masaryk, Comenius, and Arendt. On the context of Patočka's thought, see Kohák 1989: 3-135. On Patočka's reading of Arendt, see Patočka 1996: 14-16, 37-40. On Patočka's reading of Husserl, Heidegger and Fink, see Dastur 2017: 149-166.
} 
129) argues that Husserl ends up eliminating transcendence as transcendence, interpreting it in the light of the thesis about the dominance of immanence. What reduction achieves through its intuitive approach is only an ahistorical subject: an abstract, uninterested observer. ${ }^{17}$ Although this interpretation of Husserl's thought may be questioned, it does show the general thrust of the arguments put forward by Patočka. If reduction should not be interpreted as establishing an area of immanence, its effect is totally opposite because it enables to account for the phenomenological field as the proper area of phenomenological studies. This explains the asubjective direction of Patočka's philosophy: it is not subjectivity that is the focus of phenomenology as an area of study but the phenomenal field itself, i.e., phenomena as phenomena. ${ }^{18}$ This authentic task of reduction-the disclosure of phenomena-is present in epoché which, in a strict sense, precedes reduction (Novotný 2003).

For Patočka, reduction - understood as a focus on immanence-is an insufficient method because it assumes an inadequate ontology. In the end, its purpose is to establish the domain of absolute being. Here, the purpose of reduction has a positive meaning as it is filled with the content of the ontic foundation of certain knowledge. In this context, epoché, properly understood, stays ontologically neutral, as it were. One might say that it is an expression of radical negativity as it leads to that which "pre-exists" and is neither worldly nor un-wordly (Patočka 1988: 257). Put simply, epoché makes it possible to account for the absolute Nothing, i.e., a transcendental life that, by definition, cannot be made real. ${ }^{19}$ Indeed, transcendental life is an existence that presents itself in the form of possibilities as such, i.e., possibilities that are unfulfilled and impossible to fulfil. This is achieved by suspending the thesis of the world, i.e., by epoché. Already in his habilitation thesis, Patočka (2016: 36) distanced himself from attempts to narrow down the understanding of reduction as a

\footnotetext{
17 In his Heretical Essays Patočka formulates this criticism in the following way: "[e]verything that is static points to a genesis and so to history. Thus history is the deepest content level which phenomenology can reach; yet if we understand history as something like free acting and deciding, or perhaps its fundamental presuppositions, then we nee to say that Husserl's genesis, though transcendental and precisely as transcendental, can know only those structures which can be grasped in the reflection of the impartial, disinterested spectator, that is, of a subjectivity that is fundamentally ahistorical in our sense of the term. If the 'phenomenon' of phenomenology is the deep phenomenon-not the 'vulgar' phenomenon that simply manifests itself, but rather its concealed enabling presuppositions in transcendental genesis-then we need to note that grasping it presupposes a fundamentally 'ahistorical' subjectivity because it is a disinterested one" (Patočka 1996: 45-46).

18 "Der tschechische Philosoph wendet sich hier gegen Husserl, der durch die Epoché das Apriori des Erscheinens auf ein bestimmtes Erscheinendes—nämlich das Subjekt—reduziert hat, während es sich für Patočka um eine Epoché handelt, die das Apriori des Erscheinens als unabhängig von jedem Erscheinenden (sei es subjektiv oder objektiv) offenbart. (Was 'A-Subjektivität' in der Phänomenologie Patočkas bedeutet, ist aus diesem neuen Verständnis der Epoché abzulesen). In der Tat, die Epoché wird nicht mehr als ein theoretischer Akt aufgefaßt, der die Welt als Phänomen in ein residuales Bewußtsein rückt. Vielmehr kommt durch diese radikale Einklammerung die Geltung alles Seienden (inklusive des Subjekts) in die Schwebe, während das Offene, der Bereich des Nicht-Seienden, kurz, das Erscheinen als solches, aufscheint" (Santos 2007: 313).

19 As Patočka maintains, "[t]ranscendental life does not exist," and he adds, "[i]f we call 'world' the universe of what exists as the object of possible natural thesis, then we must admit that transcendental life does not appear in the world, that among existent things it is nowhere to be found" (Patočka 2016: 36). On Patočka's philosophy as a form of meontology and henology, see Barbaras 2010.
} 
method of epistemological importance used to ascertain "totally sure, apodictically certain cognitions". Thus understood, epoché is a "destruction of the natural attitude characterized by the thetic habitus" (Patočka 2016: 36). Epoché, whose function is to suspend the generally applicable thesis of the natural attitude, is therefore understood by Patočka as breaking free of the world and accounting for the world as a problem. Before epoché, the world appears obvious because it never occurs as a problem that could be questioned. ${ }^{20}$

As we can see, epoché is a shock for human existence and a destruction of the natural attitude. This aspect of epoché seems to correspond with Patočka's conception of the three movements of existence, i.e., acceptance, defence and truth. Patočka describes the first of these as man's entry into the domain of an open and individual being, his existence being understood as a mutual union (harmonia) (Patočka 1996: 29f.). Even though, initially, a human being feels the strangeness of being, he finally becomes united with it. The union, however, is shaken when man realizes that he carries the burden of work. ${ }^{21}$ This is expressed by the second movement of existence. In this movement, man is totally engrossed in fulfilling his needs in order to sustain himself. Work appears to be an onerous obligation. It is only in the third movement that man breaks free of the natural being. This movement is expressed in the distance that opens up a new dimension of the world. Patočka (1996: 33) describes it as becoming open to the future and to what is supernatural. The point is that existence in this movement is no longer related with the past (acceptance) or the present (defence) and can pose questions about the world as a whole. It is only the third movement of existence that can problematize the world as the world and makes it possible to ask about the truth. One might say that, in this movement, existence becomes what it has always been, i.e., freedom that transcends the world. Before rising the question of freedom, it is important to emphasize that Patočka's doctrine of the three movements of existence describes a broader phenomenon than just philosopher's attitude. As mentioned, the movements are inherent to the human existence in general and in this sense the third movement is not a privilege of the philosopher. Rather epoché presents one of possible ways-besides, e.g., art, or work-to problematize the obvious. But if this is the case, according to Patočka, the third movement can be motivated by non-philosophical factors, and for this reason, the beginning of philosophy can be seen in non-philosophical domain. ${ }^{22}$

The problem of freedom in Patočka's philosophy may be considered in many, rather loosely related, contexts. One might argue, for example, that the introduction of the theme of freedom is related to redefining the concept of the subject from the Cartesian res to the subject of freedom (Sroda 1990). What is more important for our discussion, however, is the link established between freedom and the care for the

\footnotetext{
${ }^{20}$ In his Heretical Essays Patočka (1996: 32) describes this aspect of the world, i.e., its obviousness, as the prehistoric world.

21 Patočka emphsizes that ,[a]s soon as we become links in the chain of acceptation, we are eo ipso potential participants in work; already the child prepares for it; this preparation is already itself incipient work," and he adds, "[t]he fundamental trait of work, however, is that is is involuntary; we accept it under duress, it is hard, it is a burden" (Patočka 1996: 31).

${ }^{22}$ I am thankful to the anonymous reviewer of the Human Studies for this suggestion.
} 
soul that is eventually presented as the care for the truth. In the most general terms, Patočka understands the care for the soul as the process of shaping and developing humanity. It is thanks to epoche that man is able relate to the entire world and break free of obviousness in order to fashion himself into the subject of freedom, even if short-lived and random. In this perspective, epoché expresses the same tendency which runs through philosophy from Plato, i.e., it shows that philosophy begins in astonishment. To phrase it differently, epoché brakes the obvious what enables one to question it. What, then, makes phenomenology different than this general tendency? Contra Plato, phenomenology_according to Patočka (1989: 204-206) who labels his doctrine as a negative Platonism-does not lead towards metaphysics, but rather towards systematic descriptions of what is given. In short, epoché leads beyond metaphysics by revealing how the "obvious" gains its validity as given. ${ }^{23}$ From yet another perspective, epoché leads to freedom in that it allows naive obviousness to be overcome. In a nutshell, it is the transcendence of obviousness. Patočka describes the moment of transcendence as a "shock" and a question that expresses astonishment because - as he writes in the Heretical Essays - "[t]he uncovering of Being itself ... takes place in philosophy and in its more primordial, more radical questioning" (Patočka 1996: 49). It is this questioning that lays bare the problematic nature of the world. Questioning is also the fullest manifestation of the care for the soul that strives for the truth about itself and the world. Thus, thanks to epoché, the world appears and becomes discovered as problematic, whereas "[p]hilosophy speaks from an awareness of the problematic nature to a problematic awareness" (Patočka 1996: 142). This is why, following Patočka's argument, "[i]f we are now to grasp purely that which shows itself, phenomena, we must carry out a suspension, and 'epoch $\bar{e}$ ' of all interests and of all belief in objectivities as such beyond what simply presents itself. The epoche is neither a denial of existence nor a doubt about it, nor a pure abstraction, rather, it is a free act which does not have to do with things and as such is always possible" (Patočka 1996: 151). Thus understood, epoché is a radical "no," a protest against the world's obviousness. It seems that it is only this attitude that enables obviousness to be accounted for as obviousness.

Patočka's (2016: 6) habilitation thesis already underlines that " $[\mathrm{t}]$ he problem of philosophy is the world as a whole". One might venture an opinion that the entire philosophy of the author of the Heretical Essays is an attempt to further explore and better understand this problem. It seems that Patočka's reflections on epoché and reduction were aimed at accounting for how the world as a whole may be a problem of philosophy and how it is generally presented as problematic. As we have seen, epoché corresponds to the radical "shock" of human existence which begins to take care of the soul in its pursuit of truth. Thus, in Patočka to live in truth is to live in the question posed on the basis of recognized problematicity. The "shock" is expressed in radical questioning which, eventually, conveys the paradoxical knowledge about ignorance because - as Patočka explains_- "[t]his knowledge is characterized as the learned ignorance, that is, as a question. Socrates is the great questioner", adding,

\footnotetext{
${ }^{23}$ I am thankful to the anonymous reviewer of the Human Studies for a helpful comment on this aspect of Patočka's philosophy.
} 
"Socrates' mastery is based on an absolute freedom: he is constantly freeing himself of all bonds of nature, of tradition, of others' schemata as well as of his own, of all physical and spiritual possessions" (Patočka 1989: 180). Hence, to sum up the achievements of the Czech philosopher, one might stress that, for Patočka, reduction, understood as epoché, is not an experience of anything (e.g., a transcendental subjectivity), but that the experience is a man accounted for as a movement of existence. It is so since-as Patočka writes in the Negative Platonism:

The experience of freedom contains no vision, no final terminus, which our activity, ever object oriented, could grasp. The experience of freedom has no substrate, if by a substrate we understand some finite and positive content, some subject, some predicate, or some complex of predicates. It has the negative character of a distance, of a remove, of an overcoming of every objectivity, every content, every conception, and every substrate. That is most evident in its global character. It is this experience that first transforms our experience of objects into an experience of the whole. Only because we are always beyond all objectivity, because no objectivity is adequate to it, does the whole confront us, since as an actual aggregate of all finite beings it is, naturally, quite inaccessible to us. (Patočka 1989: 196)

\section{Conclusions}

In this article, I attempt to describe reduction as the beginning of philosophizing, focusing on questions such as: What motivates a phenomenologist to perform reduction? How is reduction the beginning of philosophizing? Can one talk about philosophy before reduction? Finally, what is the essence of reduction? Confronting these questions, I have drawn upon reflections of Husserl, Fink and Patočka, philosophers who seem to treat the problem of reduction and the beginning of philosophizing as one of the central issues. In conclusion, it is beyond any doubt that these three thinkers stressed different aspects in their definitions of reduction. And so, for Husserl, reduction is related to the need to understand the world that appears incomprehensible. The aim is to account for obviousness as obviousness to be able to study it systematically. Reduction is not motivated, however, by any element of the natural attitude because this attitude exists only after reduction. This is why Husserl treats reduction as an expression of the freedom of the philosopher who constitutes himself as the subject of philosophy. With this meaning in mind, one cannot reasonably talk about philosophy before reduction. According to Fink, reduction should also be accounted for as unmotivated. This leads Husserl's assistant to advance a thesis about the paradox of reduction that concerns the natural attitude but cannot find a foothold in it. Eventually, Fink suggests we should talk of situating reduction in the natural attitude which transcends itself in the will to be free. Patočka's philosophy, on the other hand, challenges the limited understanding of reduction as narrowing down the field of study to immanence. Here, epoché is understood as an act of freedom or overcoming the obviousness of the natural world to account for it 
in problematicity. According to Patočka, reduction is manifested in continuous questioning which strives to attain the truth.

The theoretical proposals presented above differ in several important areas, not only when it comes to the understanding of individual stages of reduction, but also the context in which the problem of reduction should be considered. It seems that, for Husserl, this context is provided by epistemological investigations and inquiries about knowledge. Fink tries to move the discussion to the level of ontology, or rather beyond it, to meontology. For Patočka, the proper dimension for posing questions about reduction is the practical domain. In spite of clear differences, all these proposals do have some points in common. One of these is undoubtedly freedom as the essence of reduction and epoché. Husserl, Fink and Patočka all treat reduction as an expression of the freedom of the philosopher who wants to go beyond the naivety of the world and obviousness. In fact, freedom begins with philosophy through reduction. As such, it is a correlative of astonishment. In this aspect, all three philosophers express intuitions already referred to by Plato and Aristotle. After all, astonishment is the beginning of wisdom, and of philosophy. If one assumes that, putting their differences aside, Husserl, Fink and Patočka share their views on the essence of reduction, then reduction could be accounted for as unmotivated, albeit situated, as well as volitional in the sense of being a specific attitude whereby the philosopher constitutes himself as the subject of freedom. This description provides additional arguments in favour of Mohanty's (1997: 57) account, quoted at the beginning of this article, according to which reduction is unmotivated and, as such, it is an exercise in freedom. Thus, the philosopher sets himself free of the naively accepted obviousness, wanting to account for it as a problem. The point is that the obviousness of the world does not in fact exist: it is incomprehensible as obviousness. In this context, reduction is used to problematize what seemed to be impossible to present as a problem. In a word, it marks the beginning of philosophy because it leads beyond obviousness. One may therefore conclude that phenomenology is a philosophy of beginnings not because it helps constitute a new area of being but because it is a process of starting anew through continuous and renewed problematization of what presents itself in experience.

In conclusion, we may argue that, following reduction, what is given is basically the same, but it is accounted for as constituted by the transcendental consciousness in a free act. What changes is the attitude, not the subject. Therefore, subjectivity stops being anonymous as it constitutes itself as a free subject and a subject of philosophy. This change is of fundamental importance. Already Husserl underlined that the change is eventually to encompass the entire life, which means that reduction is supposed to be a habitual disposition, i.e., a fixed attitude (Husserl 2002b: 106). In this sense, we showed that reduction is not a departure from the world but its restitution (Husserl 2002b: 427). Ultimately, before reduction, the philosopher cannot account for the world in its naivety and ask about its acceptance as such. What then is reduction? It is the act of taking responsibility for doing philosophy, or rather taking philosophy seriously, which, in turn, marks its beginning.

Acknowledgements I would like to express my gratitude to the two anonymous reviewers of the journal for their helpful suggestions and inspiring comments. 
OpenAccess This article is distributed under the terms of the Creative Commons Attribution 4.0 International License (http://creativecommons.org/licenses/by/4.0/), which permits unrestricted use, distribution, and reproduction in any medium, provided you give appropriate credit to the original author(s) and the source, provide a link to the Creative Commons license, and indicate if changes were made.

\section{References}

Barbaras, R. (2010). Phenomenology and henology. In I. Chvatík \& E. Abrams (Eds.), Jan Patočka and the heritage of phenomenology. Centenary papers (pp. 99-110). Dordrecht: Springer.

Bernet, R., Kern, I., \& Marbach, E. (1999). An introduction to Husserlian phenomenology. Evanston, IL: Northwestern University Press.

Boehm, R. (1981). Vom Gesichtspunkt der Phänomenologie. Zweiter Band. Studien zur Phänomenologie der Epoché. The Hague, Boston, London: Martinus Nijhoff.

Bostar, L. (1994). Reading Ingarden read Husserl: Metaphysics, ontology, and phenomenological method. Husserl Studies, 10, 211-236.

Bruzina, R. (1998). Jan Patočka und Eugen Fink, Gesprächspartner im Denken über den Schein hinaus. Internationale Zeitschrift für Philosophie, 1, 110-124.

Bruzina, R. (2004). Edmund Husserl \& Eugen Fink. Beginnings and ends in phenomenology, 19281938. New Haven, London: Yale University Press.

Cairns, D. (1976). Conversations with Husserl and Fink. The Hague: Martinus Nijhoff.

Dastur, F. (2017). Questions of phenomenology: Language, alterity, temporality, finitude (Trans. by Robert Vallier). New York: Fordham University Press.

Fink, E. (1966). Studien zur Phänomenologie 1930-1939. Den Haag: Martinus Nijhoff.

Fink, E. (1995). Sixth cartesian meditation. The idea of a transcendental theory of method. With textual notations by Edmund Husserl (Trans. by Ronald Bruzina). Bloomington, IN: Indiana University Press.

Fink, E. (2006). Phänomenologische Werkstatt. Teilband 1: Die Doktorarbeit und erste Assistenzjahre bei Husserl. Freiburg, München: Verlag Karl Alber.

Fink, E. (2008). Phänomenologische Werkstatt. Teilband 2: Die Bernauer Zeitmanuskripte, Cartesianische Meditationen und System der phänomenologischen Philosophie. Freiburg, München: Verlag Karl Alber.

Heitz, M., \& Nessler, B. (Eds.). (1999). Eugen Fink und Jan Patočka. Briefe und Dokumente 19331977. Freiburg, München, Prag: Oikúmené-Verlag Karl Alber.

Husserl, E. (1959). Erste Philosophie (1923/24). Zweiter Teil. Theorie der phänomenologischen Reduktion. Hrsg. v. Rudolf Boehm. Husserliana: Edmund Husserl Gesammelte Werke (Bd. 8). Haag: Martinus Nijhoff.

Husserl, E. (1960). Cartesian meditations. An introduction to phenomenology (Trans. by Dorion Cairns). The Hague, Boston, London: Martinus Nijhoff.

Husserl, E. (1968). Phänomenologische Psychologie. Vorlesungen Sommersemester 1925. Hrsg. v. Walter Biemel. Husserliana: Edmund Husserl Gesammelte Werke (Bd. 9). Den Haag: Martinus Nijhoff.

Husserl, E. (1970). The crisis of European sciences and transcendental phenomenology: An introduction to phenomenological philosophy (Trans. by David Carr). Evanston, IL: Northwestern University Press.

Husserl, E. (1982). Ideas pertaining to a pure phenomenology and to a phenomenological philosophy. First book. General introduction to a pure phenomenology (Trans. by Fred Kersten). The Hague, Boston, Lancaster: Martinus Nijhoff.

Husserl, E. (1984). Einleitung in die Logik und Erkenntnistheorie. Vorlesungen 1906/07. Hrsg. v. U11rich Melle, Husserliana: Edmund Husserl Gesammelte Werke (Bd. 24.) Dordrecht, Boston, Lancaster: Kluwer Academic Publishers.

Husserl, E. (1994). Briefwechsel. Band III. Die Göttinger Schule. Hrsg. v. Karl Schuhmann. Dordrecht, Boston, London: Kluwer Academic Publishers.

Husserl, E. (1996). Logik und allgemeine Wissenschaftstheorie. Vorlesungen 1917/18 mit ergänzenden Texten aus der ersten Fassung von 1910/11. Hrsg. v. Ursula Panzer. Husserliana: Edmund Husserl Gesammelte Werke (Bd. 30). Dordrecht, Boston, London: Kluwer Academic Publishers. 
Husserl, E. (1999). The idea of phenomenology. A Translation of Die Idee der Phänomenologie Husserliana II (Trans. by Lee Hardy). Edmund Husserl: Collected works (Vol. 8). Dordrecht, Boston, London: Kluwer Academic Publishers.

Husserl, E. (2001). Allgemeine Erkenntnistheorie. Vorlesung 1902/03. Hrsg. v. Elisabeth Schuhmann. Husserliana: Edmund Husserl Materialienbände (Bd. 3). Dordrecht, Boston, London: Kluwer Academic Publishers.

Husserl, E. (2002a). Natur und Geist. Vorlesungen Sommersemester 1919. Hrsg. v. Michael Weiler. Husserliana: Edmund Husserl Materialienbände (Bd. 4). Dordrecht, Boston, London: Kluwer Academic Publishers.

Husserl, E. (2002b). Zur phänomenologischen Reduktion. Texte aus dem Nachlass (1926-1935). Hrsg. v. Sebastian Luft. Husserliana: Edmund Husserl Gesammelte Werke (Bd. 34). Dordrecht, Boston, London: Kluwer Academic Publishers.

Kern, I. (1962). Die Drei Wege zur transzendental-phänomenologischen Reduktion in der Philosophie Edmund Husserls. Tijdschrift voor Filosofie, 24, 303-349.

Kohák, E. (1989). Jan Patočka. Philosophy and selected writings. Chicago, London: The University of Chicago Press.

Landgrebe, L. (1963). Husserls Abschied vom Cartesianismus. In L. Landgrebe (Ed.), Der Weg der Phänomenologie. Das Problem einer ursprünglichen Erfahrung (pp. 162-206). Gütersloh: Mohn.

Lenkowski, W. J. (1978). What is Husserl's epoche?: The problem of the beginning of philosophy in a Husserlian context. Man and World, 11(3-4), 299-323.

Lohmar, D. (2012). Zur Vorgeschichte der transzendentalen Reduktion in den Logischen Untersuchungen. Die unbekannte "Reduktion auf den reellen Bestand". Husserl Studies, 28, 1-24.

Luft, S. (2002). Phänomenologie der Phänomenologie. Systematik und Methodologie der Phänomenologie in der Auseinandersetzung zwischen Husserl und Fink. Dordrecht: Kluwer Academic Publishers.

Luft, S. (2003). Die Konkretion des Ich und das Problem der Ichspaltung in Husserls phänomenologischer Reduktion. In R. Kühn \& M. Staudigl (Eds.), Epoché und Reduktion. Formen und Praxis der Reduktion in der Phänomenologie (pp. 31-49). Würzburg: Königshausen \& Neumann.

Luft, S. (2004). Husserl's theory of the phenomenological reduction: Between life-world and Cartesianism. Research in Phenomenology, 34, 198-234.

Merleau-Ponty, M. (2002). Phenomenology of perception (Trans. by Colin Smith). London, New York: Routledge.

Mohanty, J. N. (1997). Between essentialism and transcendental philosophy. Evanston, IL: Northwestern University Press.

Moran, D. (2007). Fink's speculative phenomenology: Between constitution and transcendence. Research in Phenomenology, 37, 3-31.

Novotný, K. (2003). Die Transzendentalität der Welt. In R. Kühn \& M. Staudigl (Eds.), Epoché und Reduktion. Formen und Praxis der Reduktion in der Phänomenologie (pp. 153-175). Würzburg: Königshausen \& Neumann.

Płotka, W. (2012). Husserlian phenomenology as questioning: An essay on the transcendental theory of the question. Studia Phaenomenologica, 12, 311-330.

Patočka, J. (1970). Der Subjektivismus der Husserlschen und die Möglichkeit einer "asubjektiven" Phänomenologie. Philosophische Perspektiven, 2, 317-334.

Patočka, J. (1988). Qu'est-ce que la phénoménologie? (Tranduit par Erika Abrams, preface de Marc Richir). Grenoble: Jérome Millon.

Patočka, J. (1989). Negative platonism: Reflections concerning the rise, the scope, and the demise of metaphysics-And whether philosophy can servive it. In E. Kohák (Ed.), Jan Patočka. Philosophy and Selected Writings (pp. 175-206). Chicago, London: The University of Chicago Press.

Patočka, J. (1992). Introduction à la phénoménologie de Husserl (Tranduit par Erika Abrams). Grenoble: Jérome Millon.

Patočka, J. (1996). Heretical essays in the philosophy of history (Trans. by Erazim Kohák). Chicago, La Salle: Open Court.

Patočka, J. (2016). The natural world as a philosophical problem (Trans. by Erika Abrams). Evanston, IL: Northwestern University Press.

Santos, A. C. (2007). Die Lehre des Erscheinens bei Jan Patočka. Drei Probleme. Studia Phaenomenologica, 7, 303-329.

Sroda, K. (1990). Jan Patočka-philosophe socratique. Les Cahiers de Philosophie, 11-12, 65-82.

Staiti, A. (2009). Systematische Überlegungen zu Husserls Einstellungslehre. Husserl Studies, 25, 219-233. 
Tugendhat, E. (1970). Der Wahrheitsbegriff bei Husserl und Heidegger. Berlin: Walter de Gruyter. Zahavi, D. (2003). Husserl's phenomenology. Stanford: Stanford University Press. 